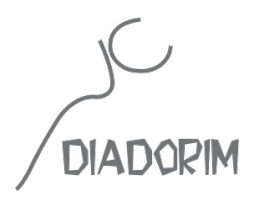

\title{
THE AMBIGUITY OF PROJECTION AND THE CHOMSKYAN ADJUNCTION AS A FORMAL WAY OF APPROACHING PREDICATION IN SMALL CLAUSES AND SECONDARY PREDICATION $^{1}$
}

\author{
AMBIGUIDADE DE PROJEÇÃO E A ADJUNÇÃO CHOMSKYANA \\ COMO UM RECURSO FORMAL PARA ABORDAR A \\ PREDICAÇÃO EM SMALL CLAUSES E PREDICADOS \\ SECUNDÁRIOS
}

\author{
Marcos Barbosa Carreira ${ }^{2}$
}

\begin{abstract}
This paper is focused on the syntax of the predication relations in predicative constructions such as the secondary predication and the small clause constructions. The goals are (i) to consider that adjunction structures à la Chomsky (1986) and May (1985) (opposing category $v s$. category segments) is an interesting solution to the syntax of predication, if combined with the idea that merge may be symmetrical in terms of projection (if $\alpha$ and $\beta$ are merged, either $\alpha$ or $\beta$ may project (CHOMSKY, 1995)); and (ii) to present a formal and unified approach to the grammar of different kinds of predication, based on Carreira (2015), specially emphasizing cases of small clauses and secondary predication. This paper presents new data from Brazilian Portuguese (BP), which challenges the classical analysis, as in Williams (1980), Stowell (1983) and Rothstein (1983) and minimalist analysis such as in Den Dikken (2006). This research is based upon the Minimalist Program by Chomsky (1995) and others. As we will argue, by exploring this mechanism, we might be able to provide a unified account for different types of predication.
\end{abstract}

1 A first draft of this paper was presented in the III GETEGRA International Workshop - Adjuncts (on March, 2018). This version was prepared during my Postdoctoral Research Fellowship at PUC-Rio (Pontifical Catholic University of Rio de Janeiro). I would like to thank Professor Cilene Rodrigues (my supervisor) for her suggestions and contributions. All remaining errors and mistakes are my own responsibility.

2 Doctor in Linguistics at UFPR and Adjunct Professor at the State University of Ponta Grossa and postdoctoral fellow at PPGEL / PUC-Rio.

\section{(cc) BY-NC}

Diadorim, Rio de Janeiro, vol. 21, Especial, p. 227-250, 2019. 
KEYWORDS: adjunction; predication structures; secondary predication; small clauses;

\section{RESUMO}

Este artigo enfoca a sintaxe das relações de predicação em construções predicativas, como a predicação secundária e construções de small clauses. Os objetivos são (i) considerar que uma estrutura de adjunção à la Chomsky (1986) e May (1985) (que oponha categoria vs. segmento de categoria) é uma solução interessante para a sintaxe da predicação, se combinada com a idéia de que merge pode ser simétrico em termos de projeção (se $\alpha$ e $\beta$ são mergidos, $\alpha$ ou $\beta$ podem projetar - Chomsky, 1995); e (ii) apresentar uma abordagem formal e unificada da gramática de diferentes tipos de predicação, com base em Carreira (2015), enfatizando especialmente casos de small clauses e predicação secundária. $\mathrm{O}$ artigo apresenta novos dados do português brasileiro (PB), que desafiam as análises clássicas, como em Williams (1980), Stowell (1983) e Rothstein (1983) e análises minimalistas como Den Dikken (2006). Esta pesquisa está enquadrada no Programa Minimalista de Chomsky (1995) e outros. Como argumentaremos, explorando esse mecanismo, poderemos fornecer uma conta unificada para diferentes tipos de predicação.

PALAVRAS-CHAVE: adjunção; estrutura de predicação; predicação secundária; small clause.

\section{Introduction}

The syntax of predication has been an area of great and productive debates within the Generative Grammar, and at least three important proposals have to be considered by anyone who wants to explore the issue: Williams (1980), Stowell (1981, 1983), and Rothstein (1983, 2001). These three different approaches dealt mostly with two pieces of data:

(1) John ate the meat raw (WILLIAMS, 1980, p. 203)

(2) Jane considers Mary smart (ROTHSTEIN, 2001, p. 43)

The predicative sequence [... V DP AP] emphasized in (1)-(2) gives us different semantic relations. In (1), the DP "the meat" is in a double thematic relation, as it is theta-marked by the verb "ate" and by the AP "raw". Here, both the verb and the adjective are in a semantic relation with the DP "the meat". This is a classical case of secondary predication, in which the adjective is not selected by the verb. Contrastively, in (2), the chunk "Mary smart" is taken as the complement of the verb. Thus, (2) is a classical case of small clause, in which "Mary" is in a thematic relation with "smart", but not with "consider", which theta-marks the whole small clause. The main question raised by these two types of predicative configurations is: what are the structures of double predications and small clauses, since different semantic relations are built in cases like (1) \& (2)? Although Stowell, William, and Rothstein present different analyses, they all share the following proposition: (a) in cases as (1), the DP "the meat" and the AP "raw" do not form a constituent; (b) in cases as (2), the DP and the AP form a constituent. This proposition offers the following structures: 
a.



b.

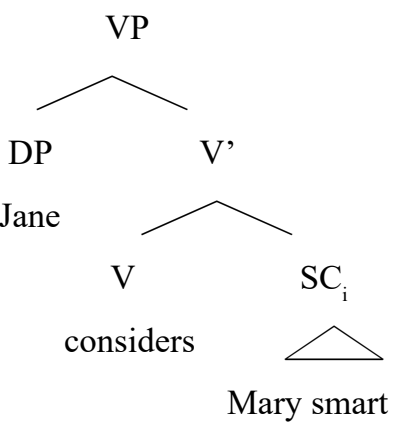

Taking (3a) and (3b) to be the right structures for (1) and (2), respectively, the Brazilian Portuguese (BP) counterpart for (1) presents itself as a problem. The sequence [DP AP] behaves syntactically as a constituent. ${ }^{3} \operatorname{In}(4)$, for example, it moves as a single phrase to the left periphery of the sentence:

(4) [esse bife mal passado] $]_{i}$ eu até comeria ...ti..., mas [ele cru]j eu não como ...tj.. 'de jeito nenhum' this beef rare I even 'would eat' but [it raw] I not eat 'not at all'. "I could eat this beef rare, but no way I would it eat raw"

Therefore, it is not clear that the structural difference proposed in (3) is in the right track.

This paper focuses on this issue. Considering data from BP and in accordance with the Minimalist Program, we will reopen the discussion related to (1) and (2). Taking into consideration the Chomskyan approach to adjunction (cf. MAY, 1985, CHOMSKY, 1986; CHOMSKY, 1995), we suggest that adjunctions arise derivationally whenever Merge combines two syntactic objects that can both define the label of the object formed (ambiguity of projection). As we will argue, by exploring this mechanism, we might be able to provide a unified account for different types of predication.

Our goals are (i) to consider that adjunction structures based on Chomsky (1986) and May (1985) (opposing category vs. segment of category) is an interesting solution to the syntax of predication, whenever combined with the idea that Merge can be symmetrical in terms of projection (if $\alpha$ and $\beta$ are merged, either $\alpha$ or $\beta$ can project (CHOMSKY, 1995)); (ii) to present a formal and unified approach to the grammar of different kinds of predication, based on Carreira (2015), emphasizing specially cases of small clauses (2) and secondary predication (1).

This paper is organized as follows: in section 1, the classical cases of predicative constructions are revisited. In section 2, the main analyses proposed so far (STOWELL,

3 There are other questions on crosslinguistic variations around this pattern of movement, but I would like to approach those questions latter in another paper, in which I will try to account for the problem of why this movement is not observed in English. 
(1981,1983), Williams (1980) and Rothstein $(1983,2001))$ are presented in a detailed way. In section 3, data from (BP) and English are introduced, showing (a) a constituency paradox from BP, as in (4); (b) an adjacency requirement on the subject and its secondary predicate - from English; (c) an interaction between VP ellipsis and secondary predication in BP, and (d) possible cases of adjectives predicating of DPs embedded within PPs in BP. In section 4, a new and unified theory of predication (UTP) is formally presented. In section 5 it is demonstrated how this theory deals with the facts presented in section 3 , and its possible consequences for formal analysis of double object constructions. Finally, section 6 is devoted to final remarks, challenges and remaining issues related to the UTP.

\section{Predicative constructions}

In this section I present some classical pieces of data of predicative constructions, such as Small Clauses and Secondary Predication. What I refer to as predicative constructions can be illustrated by the examples below:

(5) John ate $[\text { the meat }]_{\mathrm{i}}[\mathrm{raw}]_{\mathrm{i}}$

(6) $[\text { John }]_{\mathrm{i}}$ drove his car $[\text { drunk }]_{\mathrm{i}}$

(7) I consider $[\text { that boy }]_{\mathrm{i}}[\text { smart }]_{\mathrm{i}}$

(8) He hammered [the metal $]_{\mathrm{i}}[\text { flat }]_{\mathrm{i}}$

The examples in (5)-(8) are well known in the history of Generative Grammar. In (5), we say that the AP "raw" is a depictive secondary predicate of the DP "the meat" (the subject of this PS), once this DP is an argument of the verb "to eat" and receives a theta-role from it. The same thing occurs on sentence (6), but this time the subject of the secondary predicate (the AP "drunk") is the grammatical subject of the sentence, the DP "John", and the external argument of the verb "to eat". In (7) the predicate "smart" is a predicate of "that boy", but as we can see in Stowell (1981 and 1983) and Rothstein (1983 and 2001), the DP subject of "smart' is not an argument of the verb "consider" (for more detail on that, see Carreira (2015) and the references above). As the previously cited authors pointed out, it seems that the predicate "smart" is somewhat selected by the verb "consider" (hence the unacceptability of *I consider that boy). However, this pattern do not occurs in the examples (5), (6) and (8): the predicates "raw", "drunk" and "flat" are not select by the verb "to eat" and "to hammer", respectively. We say they are adjuncts. The example in (8), however, is a bit different from (5) and (6), once the AP "flat" expresses not just a state of one participant of the main event (during that event), but instead it express the state of the object participant as a result of the main event process (for more information on that, please refer to Knöpfle (2014)).

Brazilian Portuguese (BP) shows some interesting properties of predicative constructions, which may help understanding this phenomenon and its complexity. Consider the set of 
data presented below:

(9) João comeu as cenouras cruas

João eat the $\operatorname{lFEM/PL]}$ carrots $_{[F E M / P L]} \operatorname{raw}_{[F E M / P L]}$

Reading-1: "João ate the raw carrots"

Reading-2: "João ate the carrots raw"

The utterance in (9) has two possible reading, as we can see above. This two reading are known as attributive (reading-1) and predicative (reading-2). I am interested here mainly on the predicative reading, but Carreira (2015) has defended that both reading may be unified as predication, once "raw" means something like a property, either in reading 1 or in reading 2.

Those two readings seem to be the result of two different composition in syntax, and as any introduction to syntax of BP says, the two cleft below may be good constituent test to that conclusion:

(10) Foi a cenoura que o João comeu _ crua (predicative)

It was the carrots that João ate raw?

(11) Foi a cenoura crua que o João comeu _(attributive)

It was the raw carrots that John ate

Therefore, from examples (10) to (11), we make those claims for BP: (i) the AP in attributive reading and in predicative reading appears after the noun, in contrast with English and German in which those two reading is expressed through a different word order; (ii) the adjective agrees with gender and number with the DP/NP it is related to, its subject. The same pattern of agreement holds on small clause constructions, as we can see in (12) below:

\section{(12) Marcos considera suas alunas espertas \\ Marcos considers his students ${ }_{[F E M / P L]}$ smart $_{[F E M / P L]}$}

Hence, as we see in BP, the AP "cruas" and "espertas" above presents gender and number morphology, once they agrees with the subject in gender and number features. The same thing does not occur in English and German, as we see below:

(13) (01) John ate the meat raw

(14) João ass das Fleisch roh.

(CARREIRA; KNÖPFLE, 2013)

João comeu a carne cru

"João comeu a carne crua"

The example (13) is interesting, if we contrasts it with its attributive counterpart "João ass das rohe Fleisch", because, in (13), the adjective appears without any agreement morpheme, but in the attributive reading, this adjective comes before the noun and shows gender, number and case agreement (CARREIRA; KNÖPFLE, 2013). 


\section{Classical analysis}

The debate around the predication relation structure has taken two different directions in the 1980's. One direction goes is related to the Predication Theory, developed by Williams (1980, 1983). The other direction is related to the Small Clause Theory, developed by Stowell (1981, 1983). There was a third view, mainly cited as Complex Predication, developed by Chomsky (1955) (for more information on that, please refer to CARDINALETTI \& GUASTI (1995)). Those three predication structure views can be summarized as Den Dikken (2006) did and I repeat it below:

(15) a. $\left[{ }_{V P}\right.$ V DP Pred]

(15) b. [ [ $\left[{ }_{V P}\right.$ V Pred] DP $]$

(15) c. $\left[{ }_{V P} V\right.$ [DP Pred] $]$

The three structures above represent three ways the researcher had used to accommodate the grammar of these constructions: as we can see, (15)a is a ternary branching structure which was excluded from the mainstream of the Generative Grammar on the assumption that "a theory of n-ary branching is less restrictive than one that restricts phrase structure to binary branching configurations" (DEN DIKKEN, 2006, p. 59) and on the assumption that "from a learnability perspective the latter [binary] is therefore to be preferred" (DEN DIKKEN, 2006, p. 59); however, Williams (1980, 1983) and Rothstein (2001) have adopted it to describe object-oriented secondary predication constructions, but only Williams has used it to describe canonical small clauses; (15)b was adopted by Chomsky (1955) to solve the problem with the consider-type verbs, and to maintain the rule of passivization adopted, without a novel rule; (15)c was adopted by Stowell (1981, 1983), Chomsky (1981), Rothstein $(1983,2001)$ and Den Dikken (2006), inter alia, once it takes de predication structure to be the sister of $\mathrm{V}$, hence to be in its complement position.

There is still another structure that was adopted by Tim Stowell, since (15)c was used specifically to describe cases of complementation of consider-type verbs, or constructions where the predicative form a constituent which is positioned at the compl of V. It is worth noting that Stowell $(1981,1983)$ and Rothstein (1983) adopt, for constructions of secondary predication like "john ate the meat raw", a structure with the AP in an adjunct position somewhere high in the VP. Then we have something like (16)a or (16)b, where AP counts as 'Pred'.

(16) a. $\left[{ }_{V P}\left[{ }_{V P} V\right.\right.$ DP $]$ Pred $]$

b. $\left[{ }_{\mathrm{VP}}[\mathrm{VP} V \mathrm{DP}] \mathrm{AP}\right]$

Stowell postulates a PRO in AP's spec controlled by the object of the verb, in contrast with Rothstein, since he assumes the AP is an adjunct small clause. The following trees, in which the VP with a secondary predicate and a VP with a SC is contrasted, illustrate the previous statement: 
(3) a.





The structures (3), originally demonstrated on the introduction, constitute what I am naming the classical proposal, and they share the properties of postulating the following: (a) for examples like (5) and (17) - repeated below - the DP "the meat" and the AP "raw" do not form a constituent - call this the non-constituency property of SP; and (b) for examples like (7) and (18), in contrast with (5) and (17), the DP and the AP form a constituent, i.e., DP "that boy" and the AP "smart" form a constituent, as we saw previously in the trees in (3):

(17) John ate $\left.\left[_{\mathrm{DP}} \text { the meat }\right]_{\mathrm{i}[\mathrm{AP}} r a w\right]_{\mathrm{i}}$

(18) I consider $\left[{ }_{\mathrm{DP}} \text { that boy }\right]_{\mathrm{i}}\left[_{\mathrm{AP}} \text { smart }\right]_{\mathrm{i}}$

Williams $(1980,1983)$ is not represented in the trees $(3)$, but as we saw on the structures on (14), he goes on the same road of Stowell and Rothstein in taking the non-constituency property of $S P$ (although Williams himself did not treat these cases as secondary predication, but as thematic governed predicates - refer to Williams (1983)).

To develop my proposal here, I will take the example of secondary predication and the non-constituency property of the classical proposal to the cases of secondary predication as a starting point.

In the next section, I present some challenging facts to the classical analysis presented by BP.

\section{Challenges to the classical analysis}

In this section, I introduce data mainly from Brazilian Portuguese (BP) that presents itself as challenging to the classical analysis. This data constitutes what I am calling the empirical complexity. The subsections below present the following phenomena: (a) the Constituency Paradox from BP involving the secondary predication; (b) an adjacency requirement on the subject and its secondary predicate - examples from English; (c) an interaction between VP ellipsis and secondary predication in BP; and (d) possible cases of adjectives predicating of DPs embedded within PPs in BP. 


\section{The Constituent Paradox}

If we assume that the right analysis to the grammar of secondary predication are the ones presented in the previous section, we will need to find an account to the constituent paradox presented in this subsection. Consider the example in (1) repeated below (reading-2) as (21) as a departure point:

\section{(19) João comeu a carne crua}

João ate the meat raw

Reading-2: "John ate the meat raw" (predicative)

When we apply some basic constituent tests to (19), considering the predicative reading (or depictive, as in Himmelmann \& Schultze-Berndt (2005)), the results seems to be awkward, and I bit degraded:

\section{(20) ? A carne crua, Pedro comeu $\quad \rightarrow \quad$ (reading-2 seems to be unavailable)}

(21) the meat raw, Pedro ate

However, in a contrastive focus context, this movement is perfect in BP, as we can see below, in (22):

(22) [esse bife mal passado] ${ }_{i}$ eu até comeria ...t. $t_{i}$. . mas [ele cru] $]_{j}$ eu não como ...tj.. 'de jeito nenhum' this beef rare I even 'would eat' but [it raw] I not eat 'not at all'. "I could eat this beef rare, but no way I would it eat raw"

The evidence we have in (22) is much clearer if we observe the sequence of moved elements in the first part of the sentence, [esse bife mal passado], and the moved expression in the second conjunct, [ele cru]. The sequence [ele cru] "it raw" is clearly an instance of predicative reading (reading-2). So this is a case of secondary predication structure, surprisingly moved up to the left periphery of the sentence.

That said, we might conclude that a Predication Structure (PS) may be moved together as if it is a constituent; however, this conclusion is not supported by the classical analysis, since it postulates the non-constituent property of secondary predication. This is unexpected and it constitutes a constituent paradox. Someone may argue it could be a case of multiple movements, of independent constituent, however (23) shows that it is not the case:

(23) * [esse bife $]_{j}$ com certeza [mal passado] ${ }_{i}$ eu comeria $t_{j} t_{i}$, mas [ele $]_{k}$ de jeito nenhum this beef for sure rare I 'would eat' but it noway $[\mathrm{cru}]_{\mathrm{k}}$ eu não como .... $\mathrm{t}_{1} \ldots \mathrm{t}_{\mathrm{k}}$. raw I not eat 
In (23), I made a test using the phrase $\left[_{P P}\right.$ com certeza] "for sure", which is an VP adjunct, and which clearly intervening between $\left[_{D P}\right.$ esse bife $]$ and $\left[_{A P}\right.$ mal passado]. However, if we take the adverbial PP as a VP adjunct, and we assume that the phrase of the secondary predicate is also an adjunct of VP, the prediction would be that (23) should be grammatical ${ }^{4}$, if we could have multiple movements; the wrong prediction. ${ }^{5}$

The partial conclusion is that we need a constituent formed by the DP and AP in the cases of secondary predication of BP.

\section{Adjacency requirement on the subject and its secondary predicate}

There is yet another interesting empirical fact from English, first cited by Rothstein (2001), that challenges the classical analysis, as we can see below in (24):

(24) a. John eats the carrots raw with his fingers

(ROTHSTEIN, 2001, p. 125))

b. ?John eats the carrots with his fingers raw

The examples in (24), then, show that we need the AP predicate "raw" to be adjacent to the DP "the carrots", since in (24)b, where the PP "with his finger" intervenes between the DP object and the AP predicative, the sentences is somewhat degraded.

This pieces of data were present by Rothstein (2001, p. 125) as an evidence that the secondary predicates are positioned in the V level and under V'. As she says, "this is evidence that the predicate is generated at the argument level and preferably adjacent to the argument it is predicate of".

One more time, the conclusion is that the classical analysis would have problems in accommodating the date in (24), since they would predict a free interaction between the AP predicate adjunct to the VP and the instrumental PP phrase, but this is not the case.

The partial conclusion is that we need the AP to be more embedded in the VP.

\section{VP Ellipsis}

Another challenging pieces of data presented in Carreira (2015) are the cases of VP Ellipsis with the Secondary Predication:

4 There is a reading available in which the phrase [com certeza] "for sure" has scope over "mal passada", but this is not the relevant one. The PP [com certeza] must scope over the VP "comer esse bife".

5 One could say this is a case of VP fronting. However, we do not have the right semantics of topicalization or focalization of VP.

Diadorim, Rio de Janeiro, vol. 21, Especial, p. 227-250, 2019. 
(25) a. O João comeu o bolo com o garfo e a Maria também com a colher

João ate the cake with the fork and the Maria too with the spoon

b. * O João comeu a carne crua e a Maria também bem passada

João ate the meat raw and the Maria too well rosted

The comparison of (25)a and (25)b shows us that the AP "crua" and "mal passada" do not seem to be in a higher level of VP, as is the case of instrumental PP "com o garfo" and "com a colher", once ellipsis is possible in (25)a, but bad in (25)b.

The partial conclusion is that we need the AP predicate to be lower than the instrumental phrase (the PP "com o garfo" above).

\section{SP of the complement of a $\mathbf{P}$}

Another interesting and intriguing fact we may find in BP is that a secondary predicate, such as [avariado] "broken", can have a subject, like [o computador] "the computer", in a complement position of a preposition, as we can see in (26)a:

(26) a. João enviou o e-mail como computador avariado

João sent the e-mail with the computer broken

b. Com o computador avariado, não vamos entregar o trabalho em tempo

with the computer broken, we are not going to finish the work in time

Yet, it is possible to have the string "com o computador avariado" (with the computer broken) in the left periphery of the sentence, in topic position, given to the sentence a framing situation, or the circumstances in which the main event (finish the work) may (or may not) occur.

The possibility of having a subject of a SP embedded in the complement position challenges the classical proposals once they postulates that a secondary predicate should be a VP adjunct and obey some local constraint like mutual c-command or m-command.

Therefore, the fact presented in this subsection shows that even in PP, the complement of a head $P$ can be predicated by a secondary predicate phrase. This may be puzzling, once locality of predication is challenged.

Once again, the partial conclusion is that we need the AP predicate sufficient local to be in a predication relation with the complement of $\mathrm{P}$.

\section{Summarizing the Empirical Complexity}

In this section, we will see some of the challenges that poses strong difficulties to the analysis. Those challenges were related to the constituent paradox, the adjacency restriction on 
the subject of a secondary predicate (SP), the VP Ellipis interaction with SP, and that SP of a $\mathrm{P}$ complement. Those empirical facts are some of the arguments we relied on to defend a new theory of predication in syntax. Those facts gave support to a research on a Unified Theory of Predication (UTC) in syntax that I have defended in Carreira (2015).

In order to summarize the empirical complexity we have observed in this section, we conclude that any analysis that postulates non-constituency of secondary predication is going to have a hard work in order to deal with those facts.

The empirical facts listed above indicate we need at least two things:

(27) a. AP-depictive should be more embedded in VP (or in PP, or in XP);

b. AP-depictive should form a constituent with its subject.

What I am calling here as an AP-depictive is our AP in predicative position, or as a secondary predicate. If we can take the predication relation as a unified relation that happens in predicative and attributive reading, we may postulates the same base structure to both reading and leaving the difference to be a result of the interaction this structure have with the properties of the global structure within which the structure of predication (SP) is embedded.

As we can see in (26), any theory of predication in syntax should accommodate the conclusion in (27)a and (27)b.

In the sections that follow, I present a new approach to the syntax of predication, which helps us have an account of the empirical complexity shown above and some interesting prediction of some other cases of predicative constructions, and yet a grasp of a unified manner in which predication may work in the whole syntax.

\section{The syntax of predication}

In this section, I present an alternative analysis of the predicative constructions called here the Unified Theory of Predication (UTP), which was first presented in Carreira (2015). This approach relies on a derivational and minimalist view of the architecture of grammar, as in Chomsky (1995).

\section{Some properties of secondary predication of objects}

For the sake of the discussion here, let's reconsider some aspects of the example in $(01)$ repeated as (28) below:

(28) John ate [the meat $][$ raw $]$. 
The properties of (28) that are relevant to the analysis are:

- The AP "raw" denotes a property of the meat (denoted by the DP) that holds during the time of being eaten (predicative reading / depictive reading)

- The V c-selects the complement category as DP/NP (i.e, "the meat"); the V s-selects an individual with the property of being able to be eaten (i.e., s-selects "something eatable"). Summarizing, V has a subcategorization grid like this: [DP, individual].

Therefore, I am assuming that any syntactic theory of predication should provide a way of predication to happen, as well as provide the c-selection and the s-selection of $\mathrm{V}$ to happen. However, as we saw, the classic accounts have mainly two problems: (i) they do not have the right constituency (DP and AP do not form a unit); and (ii) the AP is too high in the VP structure.

\section{Den Dikken (2006)}

Once we need a constituent formed by the subject and its predicate, one could argue that a possible minimalist solution would be related to Den Dikken (2006) because his approach to the syntax of predication adopts a constituent containing the subject and the predicate in an exhaustive constituent (i.e. a constituent with the structure of predication exclusively).

Den Dikken (2006) defended a syntax of predication, in which this relation is mediated by a functional head RELATOR that has the property of postulating constituency to this relation (the $\mathrm{RP}$ projection). According to that proposal, the predication is a local relation, but a hierarchically asymmetrical one, with no apriory definition of direction on the hierarchy.

Taking Den Dikken's $R P$ as a solution to some of the questions presented above was the purpose of CARREIRA; KNÖPFLE, 2013. We tried to deal with the Constituency Paradox and to the questions of the predication relation itself using the functional null head, the RELATOR. That solution, however, is a SC analysis of secondary predication as in Stowell $(1981,1983)$, but in this case, the SC would be merged to the verbal head compl position, i.e. to the V "eat' in (23) above. Therefore, Den Dikken's analysis would encounter the same problems of the classical analysis presented here, if we try to use it to describe secondary predications of the object of verbs like "eat". See the tree below as an illustration: 


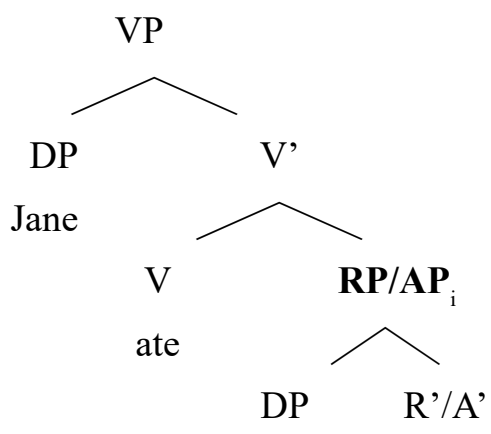

the meat

raw

As we can see in (29), the V internal argument, the DP "the meat", is positioned in the spec of the RP, and it is not a sister of the $\mathrm{V}$ head. But any proposal like the this, where the subject of the secondary predication is in spec, like in the Stowell's small clauses (the AP above), would fail to give an account for the c- and s-selection features of verbs like "eat" as in example (28), once we assume that s-selection and c-selection is established via mutual c-command or sisterhood.

The RP solution may be an interesting one to the canonical small clause data like (30), once, in (30), the verb does not c- or s-selects the DP-subject of the AP "smart", as we have seen with Stowell $(1981,1983)$ and Rothstein $(1983,2001)$.

(30) Jane considers Mary smart.

I am assuming that selection requires sisterhood of the argument with some projection of the selector, or mutual c-command. As we can see, this is not the case in the tree above. Then, how can we have the right configuration for selection, once the RP or the SC is not able to provide that? How can we deal with sisterhood and c-command and yet have the right configuration?

\section{Adjunction, label and ambiguity of projection}

One interesting way of formalizing this relation is to rely chomskyan adjunction ${ }^{6}$ (as in Chomsky 1986 and May 1985) built through the operation merge plus labeling in a derivational and minimalist view of the architecture of grammar, as in Chomsky (1995).

This approach relies on the category and segment of category distinction. So, in this system, a category in a tree structure may be formed by one or more nodes of the same categorical type, called segment of a category.

6 Chomsky Adjunction, a term used to refer to this adjunction, is an expression used since the beginning of the theory of generative grammar to refer to a specific solution to recursive structure formation, an expression first used in Chomsky (1955, chapter IX), as pointed by Guimarães (2017, p. 135). But, since Chomsky (1986), this expression is used to refer to the specific kind of adjunction just described. 
The adjunction, then, is assumed to be a minimal and symmetrical structure in which one or the other category (maximal projections) may project a new segment as the label of the new constituent just built.

Another important aspect of the system is the definition of c-command assumed. It is taken to be sensitive to the category and segment of category, in ways that make it possible the formalization of various kind of relations and maintaining its locality (as we see in GUIMARÃES (2008), KATO \& NUNES (2009), KNÖPFLE (2014), GAVIOLI-PRESTES (2016)).

The way c-command is defined relies on the notion of domination by category, so when a segment dominates a category, it does not count as dominations to the definition of c-command (see the exclusion clause on the definition of c-command on footnote 6). Refer to section 4.5. for more information on that.

Consider the predication structure (PS), as the relation in which one constituent XP is a subject and the other YP is the predicate, $\{\mathrm{XP}, \mathrm{YP}\}$. The system adopted here will first merge the SUBJECT with the PREDICATE and project one of the two constituent just merged to form a new phrase: $\{$ ? $\{$ XP, YP $\}\}$. There are two possibilities of projection (i.e., of replacing the question mark on this structure): either the SUBJECT or the PREDICATE projects the label of the adjunction ${ }^{7}$, i.e. either we have $\{\mathbf{Y P},\{\mathrm{XP}, \mathrm{YP}\}$ or $\{\mathbf{X P},\{\mathrm{XP}, \mathrm{YP}\}\}$.

The SP just formed through merge may be embedded in various environments. For the sake of our point here, consider the verbal (V) and the nominal (D) domains in (31). In this case, we will have four possible structures where predication may occur, considering those two domains, and the two possibility of projection:

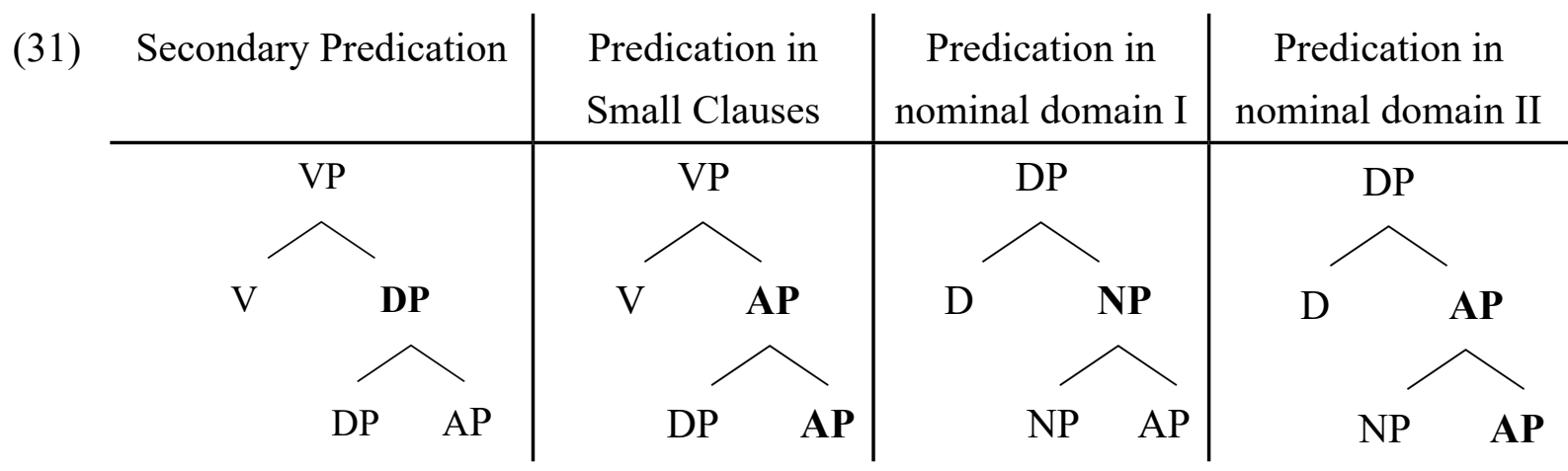

Predications can happen in A, B, C and D above, but we are interested in investigating the application of A and B. There is still some work to be done on the empirical advantages or disadvantages of a system that is able to generate $\mathrm{C}$ and $\mathrm{D}$. The structure in $\mathrm{C}$ seems to be trivial and wide used in the theory of grammar for the cases of attributive reading or nominal modification, but D seems to require more studies. ${ }^{8} \mathrm{I}$ am using AP as the predicate here, but it

7 I am ignoring the formal details of the adjunction on Chomsky (1995). For Chomsky (1995) this structure would be $\{<\mathrm{XP}, \mathrm{XP}>,\{\mathrm{XP}, \mathrm{YP}\}\}$.

8 This is an interesting fact. I am not really sure if there is no case of the D example in natural

Diadorim, Rio de Janeiro, vol. 21, Especial, p. 227-250, 2019. 
The ambiguity of projection and the chomskyan adjunction as a formal way of approaching... Marcos Barbosa Carreira

could be a PP or a CP (for a relative clause), or anything else.

How can we determine which category projects? Why can this structure give a solution to the selection problem just presented?

\section{Derivational properties: Ambiguity of projection}

How to determine which category projects in this system is an interesting and intricate question. As in Chomsky (1995, p. 244), a label "is determined derivationally", but for Chomsky (1995), the syntactic object (SO) merged determines the label of the structure. ${ }^{9}$ In general, the selectional head defines the label of the constituent just built. What I am proposing here for the PS is something different because it would involve leaving the label undefined and it would be defined only when the new formed constituent is concatenated with the next lexical (or functional) head. That way, the selection features of this head would count to define the identity of the PS constituent, as illustrated below:

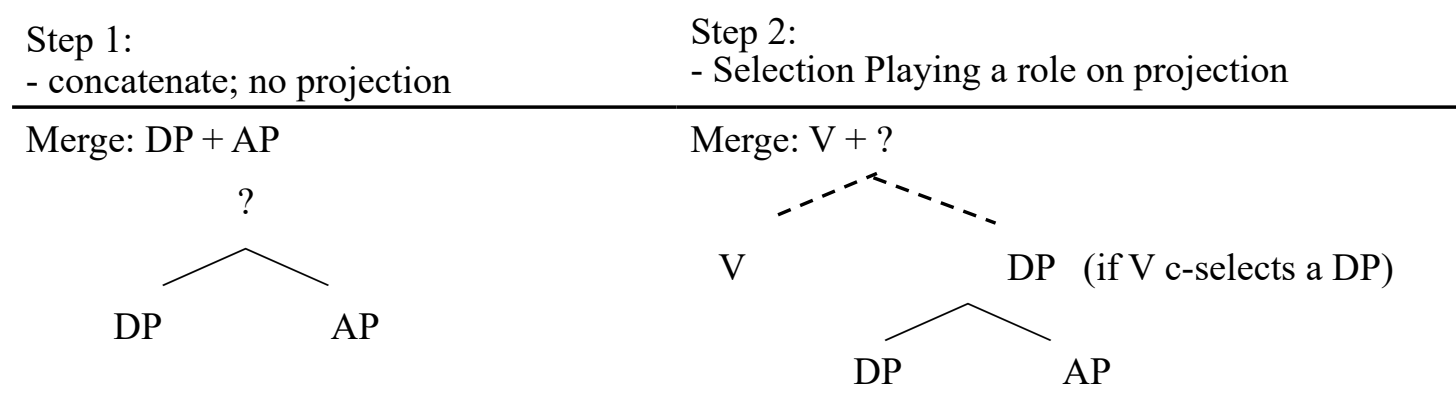

As we can see in (32), either the DP or the AP above projects the higher level, depending on the relations that the PS has with the verbal head. ${ }^{10}$ Selection of the head merged to the structure would be very important determining the label.

This 'look ahead' postulated by the process described may be challenging and not at all trivial to the computational system, but if this were the case, the ambiguity of projection and the relation with the verb may play an important role in determining whether we have a primary predication or a secondary predication. ${ }^{11}$

\footnotetext{
languages. However, if this is the case, we can give an account to that relying on the properties of the functional D head, once it may always force NP projection (not the AP), as we can see in (31).

9 It is important to remark that, on that part of the PM, Chomsky was worried about substitution, not adjunction. Some pages later, he notes that adjunction may have different ways of determining the label. 10 I am using the $\mathrm{V}$ head just as an example. It could be $\mathrm{D}, \mathrm{P}$ or any other head. As we saw on the empirical complexity, there maybe cases of secondary predication of a $\mathrm{P}$ complement; there maybe predication in the internal domain of a DP (nominal domain).

11 We are working on a system without this problem, in which the label will play no role in the description of primary and secondary predication.
} 


\section{Formal properties: category and segment of a category:}

In this section, I discuss the formal properties of this system, aiming to show the mechanics that make this an interesting and a minimal solution to the syntax of predication.

In the example (33) below, AP is a category with two segments. Take domination of category in the lines of Chomsky (1986) and May (1985), considering the c-command relations: ${ }^{12}$

Asymmetric and mutual c-command

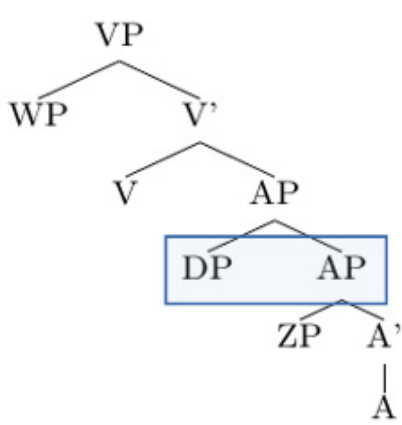

Taking the nodes highlighted by the square as the PS, the co-command relations are, considering the definition of c-command with the exclusion clause (see note 3): mutual c-command: $\{\mathrm{V}, \mathrm{AP}\}$ and $\{\mathrm{V}, \mathrm{DP}\}$; and asymmetric c-command: $\angle \mathrm{DP}, \mathrm{AP}>$. Then, DP and AP, in the PS, is in a relation of asymmetric c-command.

In a structure like (33), we have mutual c-command between V and DP. This is in interesting result for the problems in section 3 and for the requirement presented in (27) repeated as (34):

(34) a. AP-depictive should be more embedded in VP (or in PP, or in XP);

(35) b. AP-depictive should form a constituent with its subject.

In (33), we have the predication relation (in the square) and the AP predicate is sufficient embedded forming a constituent with its subject. This way in a secondary predication construction, (33) can satisfy the verb s- and c-selection straightforwardly, because the DP subject is in a mutual c-command relation with the $\mathrm{V}$ head.

There are two other nice consequences of the relations just described: (i) the DP is in the domain of two heads, $\mathrm{V}$ and A (domain as in Chomsky (1995: 178)) ${ }^{13}$, called ambiguity of domain de AP (or YP) predicate; and (ii) the AP can also be in two domains, called the visibility property of the predicative. Even if not projecting, the AP is in the domain of $\mathrm{V}$ and there is mutual c-command between $\mathrm{V}$ and AP. This is an interesting result.

12 C-command: $\alpha$ c-comands $\beta$ iff: 1) $\alpha$ and $\beta$ are categories; 2) $\alpha$ excludes $\beta$; and 3) every category that dominates $\alpha$ dominates $\beta$. Exclusion clause: $\alpha$ excludes $\beta$ if no segment of $\alpha$ dominates $\beta$. (CHOMSKY, 1986:8).

13 "Take the domain of a head $\alpha$ to be the set of nodes contained in $\operatorname{Max}(\alpha)$ that are distinct from and do not contain $\alpha . "$ (CHOMSKY, 1995: 178).

Diadorim, Rio de Janeiro, vol. 21, Especial, p. 227-250, 2019. 
I do not have everything on visibility of predictive formalized, but this is the formal property that we can use to establish the predicative reading as a reading expressed by the relation between two events and one participant, in which those events share one participant and the tense of the main event. Rothstein (2001) has proposed an operator, the TPconnect, which works in her semantics representation. Inspired on that, I think we can have this as a result of the form of syntax, once the AP is not embedded in the DP, hence visible outside.

\section{Summarizing the ingredients of predication}

This section provides us with a summary of the elements that are needed to this approach of predication to work. Some of its elements are very important to bring to this new proposal its descriptive power and advantages. See the list below:

a) Predication is a relation between two maximal projections, $\mathrm{XP}$ and $\mathrm{YP}$, in an adjunction structure, as we saw in the previous subsections. The two maximal projections as sisters, but there is no mutual c-command between them, as we see on (36) below:



In Secondary Predication the DP projects.



In Small Clauses the AP projects

b) Locality: there seems to be a consensus in the studies of the syntax of predications that this relation is local. Locality has been translated through various formal devices. For Williams (1980, 1983) locality was mutual c-command, for Rothstein (1983), mutual c-command was important, but, definition of c-command varies in including or not the higher maximal projection or the immediate dominating node. For Stowell (1981, 1983) locality meant to be in the spec position of the predicate; and to Den Dikken (2006), as being in the same phrase, in spec or compl position. For our purpose here, locality of predication means sisterhood (an asymmetrical one).

c) Ambiguity of Projection plays a role in distinguishing between depictive predication, and small-clauses predications. See the trees (36) above, where the DP projects when the verb s-selects an individual and c-selects a DP, a case of secondary predication; and the AP projects when the verb s-selects a proposition and c-selects a AP (or the like), a case of what is know as small clause (for Rothstein (2001, a case of 
primary predication).

d) Adjunction: adjunction + the distinction of category and segment of a category. This ingredient is an important aspect of the formal description, once it makes the right predictions about the way the s- and c-selection works. Besides that, this kind of adjunction make possible what I am calling "visibility". See (f) below.

If so we can have too more interesting properties:

e) Unification: the semantic relationship found in both predicative and attributive constructions is to be treated as predication. This is an interesting hypothesis to be pursued, since we can derive the differences between predicative and attributive reading as a result of the structural configuration where PS is built: if more embedded in the DP, attributive reading; if adjoined to the DP projection and visible outside, predictive reading, once in this case the AP is visible outside - see (f) below - and free to establish some relations outside the DP - see the trees in (37);

f) Visibility: as sad in (e) above, when a predicate is somewhat visible outside, visible to tense, then we have predicative reading; when a predicate is not visible to tense, then we have the attributive reading, as is illustrated in the trees below:

(37)



As we can, the APs in the trees above are in different position. The predicative reading is able only if AP is visible to $\mathrm{V}$ or $\mathrm{T}$; if it is too embedded (the adjunction is complement of $\mathrm{D}$ ), it is not visible to $\mathrm{V}$, nor to tense, so we have the attributive reading. This is very interesting and may clarify the semantic difference between attributive and predicative reading (more in CARREIRA (2015)).

\section{Applying this approach to the empirical complexity}

If this approach is on the right track, then we are able to describe movements of the PS. Therefore, we can give a solution to the constituency paradox demonstrated in section 4.1, repeated below:

(38) [esse bife 'mal passado'] ${ }_{i}$ eu até comeria .... $t_{i} .$. , mas [ele cru $]_{j}$ eu não como ...t. $t_{j .}$ 'de jeito nenhum' 
this beef 'rare' I even 'would eat' but [it raw] I not eat 'not at all'.

"I could eat this beef rare, but no way I would it eat raw"

This is so because we have the right constituency for movement, as shown in (39). The circle represents the relevant constituent, that is able to be fronted:

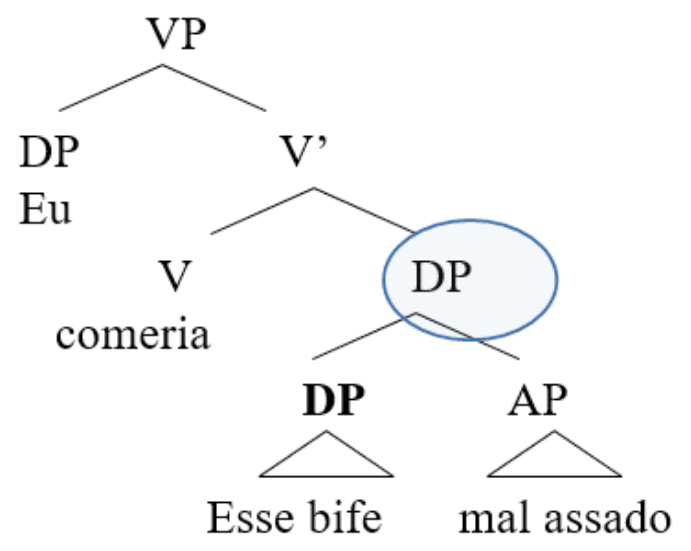

\section{The higher DP is able to move up}

The other facts presented can also be accounted for, once this account does not postulate the VP to be a VP adjunct, but to be more embedded, as an adjunct of the DP complement, in the case of secondary predication.

Therefore, the requirement of AP secondary predicate to be adjacent to its subject, the cases of VP Ellipsis, the PS of the complement of a prepositions can be trivially handled with this formulation of the syntax of predication. There is no problem for the locality of predication if the PS was put in the complement position of a $\mathrm{P}$, once the local relation is resolved through the predicate being a sister of its subject, in the asymmetrical sisterhood relation resulted from the adjunction and the segment of category distinction plus the right definition of c-command.

\section{Some nice consequences and some residual questions}

The focus of this research is the predication constructions, mainly secondary predication of the object, the canonical small clauses, some cases of copular constructions etc. However, a good theory is able to give answers to questions that go beyond its initial inquiry.

Accounting of double object constructions, or to give an answer to this classical phenomenon was an interesting result. There has been a long debate on double object constructions, aside from the classical proposal of Larson (1988).

To Double Object Construction was also treated as SC (refer to Hoekstra (1988) and Den Dikken $(1995,2006))$. And, interestingly, the formalization presented above may unify both the 
double complementation, and the SC analysis, as we can see in the tree below:
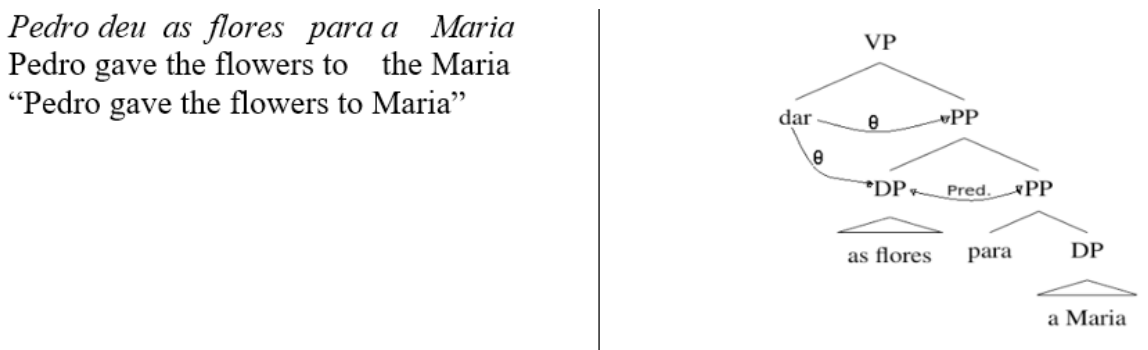

In this tree, the predication relation, as point out by Hoekstra and Den Dikken can occur between DP and PP. However, it is possible for the same structure to accommodate the theta assignment of the internal arguments in a trivial manner, through mutual c-command as represented by the arrows on the tree.

Other interesting cases are the complex copular constructions. They were in the beginning of this investigation during my $\mathrm{PhD}$ research, and it was somehow the motivation of the form of this proposal. ${ }^{14}$ They are an intriguing set of data that receives an account if this theory is on the right track.

They are sorted in two different types of constructions, as follow: (i) complex copular sentences with secondary predication; and (ii) complex copular sentences with double SC. See the examples (41) and (42):

(41) a. Maria bêbada é chata

Maria drunk is annoying ${ }_{\mathrm{FEM}}$

b. Maria é chata bêbada

Maria is annoying ${ }_{\mathrm{FEM}}$ drunk

(42) a. Maria bêbada é chato

Maria drunk is annoying $\left[_{\text {no-gender }}\right]$

b. *Maria é chato bêbada

Maria is annoying $\left[_{\text {no-gender }}\right]$ drunk

This set of data in (41) and (42) presents a real challenge to the theory of grammar, mainly if we consider the meaning and the agreement pattern of each pair, (41)a-b and (42)a-b. In (41) we have two AP, both predicating of the DP "a Maria", and the agreement holds on and is morphologically expressed on "bêbada" and on "chata", along with the possibility of the DP " $a$ Maria" to be adjacent to the AP "bêbada" (as in (41)), or separated of it (as in (41)b).

14 This utterances caught my attention, when I was a Ph.D student at UFPR, a reading in the research group (in 2011) formed with Professors Maria José Foltran, Patrícia Araújo Rodrigues, Thais Moreira and me. It was first presented in the XII Workshop on Formal Linguistes (Rio de Janeiro, 2012). These pieces of data also appeared in Foltran and Rodrigues (2013), Rodrigues e Foltran (2012), Carreira (2015) and has inspired Luana de Conto's Ph.D research (de Conto, 2018). 
On the other hand, in (44), there is a different state of affair. The two AP have different semantic values and the agreement pattern is not observed. As pointed out by Foltran and Rodrigues (2013), we have an agreement mismatch, once the AP "chato" does not agree with the DP "a Maria" (just the AP "bêbada" presents gender agreement with the DP "a Maria"). On the semantic side, the AP "chato" does not predicate of the individual "a Maria", but of a situation in which Maria participates (refer to FOLTRAN and RODRIGUES (2013), or de CONTO (2018) for more information on that).

The problem seems to be really intriguing, but I believe that the theory presented here is able to accommodate the facts just presented. Once the structures developed here are minimal, with no resort to functional projection mediating predication, we are able do embed this minimal predicate structure one in the other, and yet rely on its formal relation (c-command, sisterhood, domain ambiguity) to make predication happen. See the trees below.
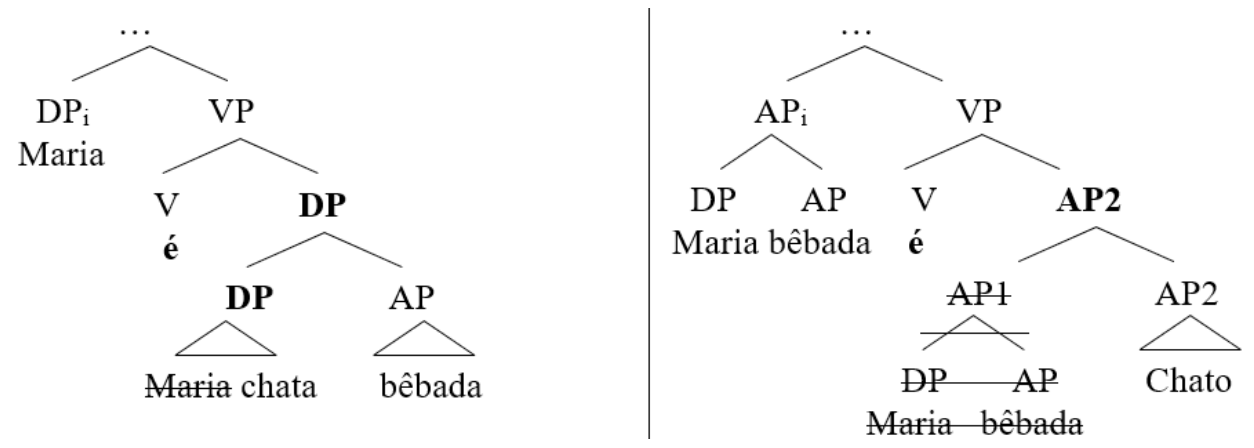

I cannot say I have a solution to the problems of agreement here (more on that on a future paper), but if the projection of the label (hence the ambiguity of projection) plays a role on that, then we may have an interesting way of accommodate the agreement pattern. However, this approach accounts for the pattern of movement and for the predications relation. We say that, in (41), the AP "chata" is in a predication relation with an individual (represented by the projection of the DP), because the DP projects and makes it possible to the DP and the AP be in the right relation, as defined before (asymmetrical sisterhood). Contrastively, in (42) the AP "chata" is in a predication relation not with an individual, but with a situation (represented by the projection of the AP - something as a small construction, as in Stowell (1981)); in this case, there is no agreement and the predication over an individual is blocked.

The pattern of movement can also be accounted because, as we can see in the trees above, in the case of the constructions with double small clauses, the AP "chato" is too high in the structure, and there is no constituent exhaustively dominating "a Maria" and "chato". One could argue that things would be different if the AP "chato" was merged to the DP "a Maria", but this would block the agreement between "a Maria" and "bêbada", if the predicate "chato" projects the label, and would force (or make free) the agreement between "a Maria" and "chato", since they would be sufficiently locally related, in the terms defined in this work. 


\section{Final Remarks}

We saw in this paper a summarized version of the Carreira (2015) theory of predication in syntax, dubbed UTP (Unified theory of Predication). This theory showed us that the distinction between the two adjunctions, as a result of the two possibilities of projection, helps us to describe the secondary predication and the small clauses constructions (secondary vs. primary predication).

We also saw the attributive and predicative reading is captured through visibility of the AP, depending on how much this constituent is (or is not) embedded in the DP.

The questions posited by the constituency paradox, the VP ellipsis, the adjacency of the subject to the predicate in secondary predicates, the complex copular sentences with secondary predication or with double small clauses are intriguing cases that we have an account with the UTP.

One nice consequence of this approach was having a new answer to the problems of double object constructions, unifying the traditional view with the view of object constructions as an instantiation of small clause structures, à la Hoekstra (1988).

Some new researches are taking the minimal and symmetrical structures proposed here, considering the ambiguity of projection and the adjunction as a possibility to account for Tough Constructions (refer to ROSE (2017)).

Further research is still necessary to show this theory can have some new applications. However, there are some residual problems this theory must face. The structures just discussed above are incompatible any version of the LCA (Linear Correspondence Axiom, as in Kayne (1994) or the PM version in Chomsky (1995). Once the system presented in this paper relies on the ambiguity of projection, and so changing the direction of c-command, the LCA will not work for the majority of the structures.

Another issue that I am paying some attention to is related to trying to develop a solution on how can we accommodate agreement in this proposal.

Some attention and some work are also required to the question of formalizing the visibility properties of the predicative reading of the AP (or any other predicative XP). This work would make it possible for us to go ahead on what I have called as the property of unification, in such a way that we could formalize in the same manner the syntax of predicative reading and attributive reading. 
The ambiguity of projection and the chomskyan adjunction as a formal way of approaching... Marcos Barbosa Carreira

\section{References}

CARDINALETTI, A.; GUASTI, M. T. Small clauses: some controversies and issues of acquisition. In: CARDINALETTI, A.; GUASTI, M. T.(Ed.). Syntax and Semantics. London \& New York: Academic Press, 1995. p. 1-23.

CARreIRA, M. B. Diagnósticos de Constituência para Construções Predicativas Adjetivais. Master Degree Dissertation, Universidade Federal do Paraná, Curitiba, 2008.

CARREIRA, M. B. Predicação e ambiguidade de projeção: uma teoria unificada. (Ph.DThesis), Universidade Federal do Paraná, Curitiba, 2015.

CARREIRA, M. B.; KNÖPFLE, A. Uma análise teórico-empírica de predicação secundária. Estudos Linguísticos. São Paulo, v. 42, n. 1, p. 182-194, jan-abr 2013.

CARREIRA, M. B.; FOLTRAN, M. J.; KNÖPFLE, A. Small Clauses: Origins and State of Affairs. Revista Linguística. V. 13 n. 2., 2017

CHOMSKY, N. The Logical Structure of Linguistic Theory. New York: Plenum, 1975. Versão publicada de um manuscrito de 1955.

CHOMSKY, N. Barriers. Cambridge/MA: MIT Press, 1986. (Linguistic Inquiry Monograph, $13)$.

CHOMSKY, N. The Minimalist Program. Cambridge/MA: MIT Press, 1995.

CONTO, L. de. Tese é complicado: a leitura de situação em cópulas com falha de concordância. $\mathrm{Ph}$. D Thesis. Universidade Federal do Paraná, 2017.

DEN DIKKEN, M. The Syntax of Predication, Predicate Inversion, and Copulas. Cambridge, MA: MIT Press, 2006.

FOLTRAN, M. J.; RODRIGUES, P. On denoting Abstract Entities. Revista da Abralin, v. 12, n. 1, p. 269-291, 2013

GAVIOLI-PRESTES, C. A descrição estrutural de orações relativas fortemente livres e construções correlatas. 2016. Tese de doutorado. Universidade Federal do Paraná, Curitiba.

GUIMARÃES, Maximiliano. Os fundamentos da teoria linguística de Chomsky. Petrópolis, RJ: Vozes, 2017.

GUIMARÃES, M. A note on the strong generative capacity of standard antisymmetry theory. Snippets, v. 18, p. 5-7, 2008.

HIMMELMANN, N. P.; SCHULTZE-BERNDT, E. Secondary Predication and Adverbial Modification: The Typology of Depictives. New York: Oxford University Press, 2005. 448 p. 
HOEKSTRA, T. Small Clause Results. Lingua, v. 74, p. 101-139, 1988.

KATO, M.; NUNES, J. A Uniform Raising Analysis for Standard and Nonstandard Relative Clauses in Brazilian Portuguese. In: NUNES, J. (Ed.). Minimalist Essays on Brazilian Portuguese Syntax. John Benjamins, 2009. p. 93-120.

KNÖPFLE, A. Resultativas em línguas ocidentais germânicas: generalizações descritivas, descobertas empíricas e questões analíticas. 2014. 246 f. Tese de doutorado. Universidade Federal do Paraná, Curitiba.

LARSON, R. On the Double Ob ject Construction. Linguistic Inquiry 19, 335-391.

MAY, R. Logical Form: Its Structure and Derivation. Cambridge, Massachusetts: MIT Press, 1985.

RODRIGUES, P.; FOLTRAN, M. J. Construções de small clauses complexas em Português Brasileiro. Estudos Linguísticos, v. 42, n. 1, p. 497-511, 2013

ROSE, Isabel Leslie. Another crack at the tough nut: a new a approach to tough and other object-gap constructions. Master Degree Thesis in Progress at PUC-Rio de Janeiro, 2018.

ROTHSTEIN, S. The Syntactic Forms of Predication. Ph.D. Dissertation, MIT, 1983. Http:// hdl.handle.net/1721.1/15509.

ROTHSTEIN, S. Predicates and their subjects. Dordrecht: Kluwer, 2001.

STOWELL, T. Origins of phrase structure. Tese (Unpublished doctoral dissertation) - MIT, 1981.

STOWELL, T. Subject across categories. The Linguistic Review, v. 2, p. 285-312, 1983.

WILLIAMS, E. Predication. Linguistic Inquiry, v. 11, p. 203-238, 1980.

WILLIAMS, E. Against Small Clause. Linguistic Inquiry, v. 14, n. 2, p. 287-308, 1983. 